\title{
Teacher Character across Levels of Study: Application of the 5 M Concept Watak Pendidik Merentas Tahap Pengajian: Aplikasi konsep 5 M
}

Nurul Asiah Fasehah Muhamad*, Noornajihan Jaafar

Fakulti Pengajian Quran dan Sunnah, Universiti Sains Islam Malaysia. 71800 Nilai, Negeri Sembilan

*Corresponding author: nurulasiahfasehah@usim.edu.my

Article history: Received: 05 August 2020 Received in revised form: 24 January 2021 Accepted: 31 March 2021 Published online: 30 April 2021

\begin{abstract}
Islamic Education Teachers have a great responsibility and role in ensuring that the Islamic Education Philosophy and the National Education Philosophy are achieved. As a catalyst for both philosophies, the educational process that should be pursued is the process of ta'dib which is the process of cultivating manners. Through the era of globalization without borders and the ever-increasing turmoil of science, society is exposed to the collapse of manners. As such, the role of GPI is increasingly challenging. Therefore, this study aims to propose a GPI character that is relevant to the study based on the recommendation of the Ta'dib Al-Attas Model and the 5 MIM Teaching Model Ab. Halim Tamuri et al. The findings of this study show that there is a focus on GPI's character based on the level of education by always putting the vision of Muaddib as the foremost. This study has implications for Islamic Education Teachers and GPI educators.
\end{abstract}

Keywords: Characteristics of Islamic Education Teacher, 5 MIM Model, Concept of Ta'dib.

\begin{abstract}
Abstrak
Guru Pendidikan Islam memiliki tanggungjawab dan peranan yang besar dalam memastikan Falsafah Pendidikan Islam dan Falsafah Pendidikan Kebangsaan dapat dicapai dengan baik. Sebagai penggerak kepada kedua-dua Falsafah ini, proses pendidikan yang harus dijalankan adalah proses ta'dib iaitu proses penanaman adab. Dalam melalui era globalisasi tanpa sempadan dan kecelaruan ilmu yang semakin membarah, menyebabkan masyarakat terdedah kepada keruntuhan adab. Justeru, peranan GPI semakin mencabar. Oleh yang demikian, kajian ini bertujuan untuk mencadangkan watak GPI yang bersesuaian dengan peringkat pengajian berdasarkan kepada saranan Model Ta'dib Al-Attas (2019) dan Model Pengajaran 5 MIM Ab. Halim Tamuri et al (2016). Kajian ini menggunakan pendekatan kualitatif dengan reka bentuk analisis dokumen. Dapatan kajian ini menunjukkan terdapat pemfokusan watak yang harus dilakukan oleh GPI berdasarkan kepada peringkat pengajian dengan sentiasa meletakkan visi sebagai Muaddib sebagai yang utama. Kajian ini memberikan implikasi kepada Guru Pendidikan Islam dan pemberi pendidikan kepada GPI terutama dalam usaha meningkatkan profesionalisme guru Pendidikan Islam dalam rangka merealisasikan Penyataan Falsafah Pendidikan Islam dan Falsafah Pendidikan Kebangsaan. Hal ini kerana, kepelbagaian watak yang sesuai dengan peringkat umur murid dan tahap pengajian membantu guru Pendidikan Islam untuk mendekati dan memenuhi keperluan murid dengan lebih berkesan.
\end{abstract}

Kata kunci: Watak Guru Pendidikan Islam, Model 5 MIM, Konsep Ta'dib.

(C) 2021 Penerbit UTM Press. All rights reserved

\subsection{PENDAHULUAN}

Guru merupakan penggerak utama kepada aspirasi pendidikan negara. Peranannya yang besar dalam melahirkan pelajar-pelajar yang memiliki nilai-nilai yang baik seterusnya memperkasakan bidang pendidikan negara tidak dapat disangkal lagi. Peranan guru sebagai agen perubahan sosial boleh direalisasikan melalui fungsinya sebagai wadah penyampai ilmu, peregu minda dan pembentuk sahsiah. Bagi menjalankan amanah ini, guru perlu memahami cabaran dan situasi masyarakat yang sedang dihadapi kini dan arif dalam memainkan peranan sewajarnya bersesuaian dengan keperluan para pelajar.

Keadaan semasa yang amat genting dengan cabaran sekularisme dan dualisme yang memberi kesan kepada dunia pendidikan turut meletakkan peranan guru yang lebih mencabar. Ia menyebabkan berlakunya kekeliruan ilmu seterusnya menyebabkan keruntuhan adab dan pemilihan pemimpin yang yang salah di peringkat masyarakat (Al-Attas,2019). Bagi mengembalikan kefahaman ilmu yang benar, sistem pendidikan harus diperkasakan terutama para guru yang menjadi penggerak utama kepada kejayaan pencapaian matlamat yang disasarkan dalam falsafah pendidikan kebangsaan. Dan ianya sudah tentu lebih dirasai berat bebanannya bagi Guru Pendidikan Islam yang merupakan ejen pembentukan akhlak dalam diri pelajar (Ab. Halim Tamuri \& Zawawi Ismail 2012). Gelaran ustaz dan ustazah yang dinobatkan kepada mereka terpikul bersama mereka tugas sebagai seorang pendakwah (Ab. Halim Tamuri \& Zawawi Ismail 2012; Asmawati Suhid 2015). Cabaran bagi menyediakan guru yang benar-benar berkualiti merupakan isu global yang menjadi perhatian 
pembuat dasar pendidikan bagi setiap negara. Namun, tanggungjawab yang lebih berat digalas oleh guru Pendidikan Islam kerana telah termaktub secara langsung dalam FPI bahawa guru Pendidikan Islam bertanggungjawab membentuk murid yang berjaya bukan sahaja di dunia dan bahkan di akhirat dengan menjadi hamba Allah s.w.t. yang berkemahiran, berkeperibadian mulia serta mempunyai pandangan alam serta cara berfikir yang dibentuk oleh ajaran Islam dan seterusnya bertanggungjawab kepada Pencipta, diri, masyarakat dan alam semesta; serta menjaga adab-tertibnya.

Penghayatan kualiti guru Pendidikan Islam yang terzahir melalui amalan seharian guru Pendidikan Islam memerlukan satu pandangan alam yang jelas akan kehidupan ini dan kehidupan akan datang. Menurut Al-Attas (2018) dan Wan Mohd Nor (2018) Pendidikan Islam adalah wadah gerak daya menanam adab yang mengandungi matlamat utama, isi kandungan dan kaedah penyelidikan. Secara teorinya, pendidikan anak-anak adalah tanggungjawab ibu bapa kini telah beralih kepada guru-guru di sekolah. Keadaan ini berikutan, masa anak-anak yang lebih banyak dihabiskan di sekolah menyebabkan peranan ini bertukar tangan. Kajian Ab. Halim Tamuri (2011) menyaksikan bahawa pengaruh guru-guru terutamanya guru-guru Pendidikan Islam dalam membentuk penghayatan beragama mereka adalah lebih besar nilai $\mathrm{r}(0.447)$ nya berbanding dengan ibu bapa (0.364). Kajian ini sekali gus menunjukkan bahawa guru, terutama Guru Pendidikan Islam mempunyai tanggungjawab yang besar dalam membentuk penghayatan agama dalam diri pelajar melalui ilmu yang benar bagi menyemaikan karektor insan beradab dalam diri pelajar. Hasil kajian ini turut disokong oleh kajian Mohd Burhan N., Tamuri A H, \& Mohd Nordin N. (2016) yang menegaskan bahawa guru adalah role model terbaik pelajar. Pengaruh mereka amat besar dalam menunjukkan contoh teladan yang baik terutama dari sudut kemahiran sosial dalam konteks pelajar yang terdiri daripada personality yang pelbagai.

Isu keruntuhan akhlak dalam kalangan remaja menyebabkan guru terpaksa berjuang untuk menggalas amanah yang telah diberi. Guru juga turut berhadapan dengan cabaran ledakan teknologi maklumat. Paparan-paparan di media elektronik mahupun media cetak menjadi tontonan kegemaran remaja pada hari ini (Nasarudin Desa @ Man, Tengku Intan Zarina Tengku Puji \& Sabri Mohamad, 2018). Ia sedikit sebanyak mempengaruhi pemikiran, sikap dan tingkah laku remaja. Oleh kerana itu, usaha penerapan dan pengukuhan kefahaman pandangan alam Islam, nilai serta identiti Muslim adalah sangat penting dalam pendidikan. Tanggungjawab besar ini tidak dapat tidak hanya mampu dilaksanakan oleh guru yang benar-benar memahami dan menghayati konsep pendidikan dalam Islam dan mengambil contoh dari utusan teragung iaitu Junjungan Besar Nabi SAW serta para sarjana Islam yang telah mengemukan pandangan serta cadangan tulus dan bernas dalam hal pendidikan mengikut kesesuaian konteks semasa. Oleh kerana perkembangan diri insan berbeza berdasarkan tahap dan kematangan masing-masing, maka amat perlu bagi seorang GPI mengambil maklum tentang peranan yang harus melatarbelakangi satu-satu tahap pengajian. Justeru, kajian ini dijalankan bagi mengaplikasikan model ta'dib Al-Attas (2019) dan model pengajaran 5M yang diperkenalkan oleh Ab. Halim Tamuri et al (2016) berdasarkan peringkat pengajian.

\subsection{TUJUAN UTAMA PENDIDIKAN MENURUT ISLAM}

Falsafah merupakan kombinasi dua perkataan Greek, iaitu philos (mencintai) dan sophia (kebijaksanaan) yang bermaksud cintakan hikmah atau pengetahuan. Ia merupakan satu bidang kajian yang luas meliputi keseluruhan bidang kehidupan manusia. Falsafah merupakan satu atau lebih penyataan yang menjadi dasar dan panduan bagi setiap aspek kehidupan manusia termasuklah aspek pendidikan. Walaupun falsafah merupakan sesuatu yang tetap dan tidak berubah, tetapi hasil sesebuah falsafah perlulah diuji dan dikaji bagi memastikan kebenarannya (al-Nahlawi 1979). Oleh kerana falsafah sebagaimana yang diamalkan di Barat, merupakan sesuatu yang dinamik yang memerlukan kepada penyesuaian zaman dan keadaaan, dalam tradisi keilmuan Islam, falsafah yang dibentuk haruslah berpandukan kepada al-Quran dan hadis Nabi s.a.w. agar relevan untuk dijadikan garis panduan dalam kehidupan manusia (Madkur 1999). Falsafah Pendidikan yang merupakan tunjang bagi sesebuah sistem pendidikan bakal menentukan objektif, metodologi, medium, sistem dan prasarana pendidikan (al-Kaylani 2002; al-Zuhayli 2000).

Falsafah Pendidikan sesebuah negara didasari oleh sejarah dan perlembagaan negara tersebut (Wan Mohd Nor Wan Daud 2018). Sekiranya diteliti Falsafah Pendidikan Kebangsaan (FPK), ternyata perlembagaan Malaysia yang mengiktiraf agama Islam sebagai agama rasmi merupakan dasar bagi FPK yang dijelaskan sebagai:

Pendidikan di Malaysia adalah satu usaha berterusan ke arah memperkembangkan lagi potensi individu secara menyeluruh dan bersepadu untuk mewujudkan insan yang seimbang dan harmonis dari segi intelek, rohani, emosi dan jasmani. Usaha ini adalah bagi melahirkan rakyat Malaysia yang berilmu pengetahuan, berakhlak mulia, bertanggungjawab, berketerampilan dan berkeupayaan mencapai kesejahteraan diri serta memberi sumbangan terhadap keharmonian dan kemakmuran keluarga, masyarakat dan negara (Bahagian Kurikulum JAPIM 2002:3).

Terdapat tiga asas falsafah pendidikan yang digarap dalam Islam sebelum ini iaitu: Keimanan kepada Allah s.w.t.; manhaj rabbani sebagai wasilah; dan kesedaran dan penerokaan terhadap ciptaan Allah s.w.t. (ayat-ayat kauniyyah) (al-Nahlawi 1979). Pendidikan dalam Islam juga bersifat syumul mencakupi hubungan dengan Tuhan, hubungan sesama manusia dan hubungan dengan alam (al-Kaylani 2002). Kertas kerja ini akan menambah sebuah kerangka baru yang dipelopori oleh Al-Attas iaitu falsafah pendidikan Ta'dib.

Falsafah pendidikan dalam Islam secara keseluruhannya memberi penekanan kepada setiap aspek dalam kehidupan manusia sebagai individu seperti intelek, rohani, emosi, jasmani dan akhlak. Al-Attas $(1980,2014,2019)$ sarjana Islam kontemporari menegaskan bahawa tujuan pendidikan bukan sahaja untuk menghasilkan warganegara dan pekerja yang baik, bahkan yang paling utama membentuk manusia yang baik sesuai dengan fitrah kejadiannya sebagai sebaik-baik penciptaan (surah al-Tin 95: 4). Bahkan penekanan kepada pembangunan diri sebagai individu bukan sahaja tujuan yang penting dalam pendidikan, namun juga sebagai strategik yang tepat dalam menangani isu pelbagai yang terbias daripada masalah kekeliruan ilmu, keruntuhan adab dan seterusnya membawa kepada pemilihan dan perlantikan pemimpin yang tidak sesuai pada suatu kedudukan (Wan Mohd Nor Wan Daud 2018). Dalam perspektif yang sama Mohd Kamal Hassan (2011) juga menekankan akan tumpuan pendidikan kepada pembangunan jiwa individu dengan merujuk kepada penyakit sosial remaja Islam masa kini ialah penyakit kompleks rendah jati diri (inferiority complex) dan kompleks rendah intelek (intellectual inferiority complex). Rentetan itu, seluruh potensi manusia yang dianugerahi Allah s.w.t. untuk menjadi khalifah harus dipupuk melalui sistem pendidikan kebangsaan bagi mengatasi masalah ini. 
Oleh kerana pendidikan agama merupakan teras kepada pendidikan peradaban manusia (Ibn Khaldun 1993), maka Kementerian Pendidikan Malaysia mewujudkan Bahagian Pendidikan Islam bertujuan memberikan perhatian eksklusif terhadap Pendidikan Islam bagi memantau guru Pendidikan Islam dan perlaksanaan kurikulum Pendidikan Islam. Hasilnya Falsafah Pendidikan Islam dibentuk dengan kenyataan:

Satu usaha berterusan untuk menyampaikan ilmu, kemahiran dan penghayatan Islam berdasarkan al-Quran dan al-Sunnah bagi membentuk sikap, kemahiran, keperibadian dan pandangan hidup sebagai hamba Allah yang mempunyai tanggungjawab untuk membangun diri, masyarakat, alam sekitar dan negara ke arah mencapai kebaikan di dunia dan kesejahteraan abadi (Bahagian Kurikulum JAPIM 2002:4).

Pendidikan Islam bukan sahaja berperanan sebagai mata pelajaran, bahkan ia melibatkan pemahaman dan penghayatan agama serta pengawalan pemikiran dalam kalangan seluruh warga pendidik yang terdiri daripada guru dan murid. Hal in selari dengan FPI yang menyebut bahawa, Pendidikan Islam bukan sekadar menyampaikan ilmu dan kemahiran, bahkan menanamkan konsep penghayatan Islam iaitu kefahaman, sikap dan amalan dalam warga pendidik. Penyataan ini turut disokong oleh Annasaii Jamar, Fatin Nazmin Mansor \& Mohd Aderi Che Noh (2020) yang menunjukkan terdapat hubungan antara menghayati nilai agama Islam dengan pemikiran, sikap dan tingkah laku seseorang.

Matlamat Pendidikan Islam seperti yang dinyatakan oleh Ibn Khaldun (1993), al-Ghazali (t.th.) dan al-Attas (2019) adalah untuk mencapai kesempurnaan kendiri yang meletakkan kesempurnaan jiwa bukannya jasad. Ini bertepatan dengan firman Allah s.w.t. dalam surah al-Fajr, 89: 27-30 yang bermaksud:

Wahai jiwa yang tenang (27) Kembalilah kepada Tuhanmu dengan hati yang puas lagi diredhaiNya (28) Maka masuklah engkau di dalam kumpulan hamba-hambaKu yang berbahagia (29) Dan masuklah ke dalam SyurgaKu (30).

Walaupun kesempurnaan kendiri itu dilihat pada sudut kesempurnaan jiwa, namun Pendidikan Islam tidak mengabaikan keperluan manusia di dunia seperti makan, pakai dan tempat tinggal. Segala keperluan ini harus dilengkapkan bagi memperoleh jiwa yang mutmainnah. Hal ini ditekankan dalam penulisan al-Ghazali (t.th.), Ibn Khaldun (1993) Muhammad Qutub (1982) dan Al-Attas (2019). Allah s.w.t. telah mengingatkan hambaNya seperti dalam surah al-Qasas, 28: 77 yang bermaksud:

Dan carilah pada apa yang telah dikurniakan oleh Allah kepadamu akan kebahagiaan hari akhirat dan janganlah engkau melupakan bahagiannu daripada dunia ini serta berbuat baiklah (kepada hamba-hamba Allah) sebagaimana Allah berbuat baik kepadamu dan janganlah engkau melakukan kerosakan di muka bumi, sesungguhnya Allah tidak suka kepada orang yang berbuat kerosakan.

Sarjana-sarjana Islam dalam bidang pendidikan seperti al-Nahlawi (1979), al-'Abrashi (1969), Said Nursi (2013), dan al-Attas (2018) telah membicangkan tentang matlamat pendidikan dalam Islam. Secara keseluruhan, 11 tujuan pendidikan Islam boleh di rumuskan seperti berikut: (1) untuk mencari redha Allah s.w.t. Ini bukan sahaja tujuan dalam pendidikan Islam bahkan tujuan kehidupan sebagai seorang muslim secara umum; (2) untuk menonjolkan kecemerlangan Islam sebagai agama yang suci lagi mulia; (3) untuk memantapkan pegangan akidah; (4) untuk memandu akal manusia agar sentiasa menghubungkan Allah s.w.t. dalam setiap tingkah laku; (5) untuk membentuk akhlak manusia sesuai dengan peranannya sebagai khalifah Allah s.w.t. di muka bumi menerusi proses ta'dib; (6) untuk mempersiapkan diri dengan bekalan untuk kehidupan di akhirat; (7) Untuk menyemai rasa cinta kepada ilmu dan berusaha menjadi orang yang berimu; (8) Untuk melengkapkan diri dengan kemahiran profesional dan teknikal untuk keperluan kerjaya bagi mencari rezeki; (9) Untuk menggilap potensi dan bakat yang dikurnikan Allah s.w.t.; (10) Untuk membentuk generasi muda yang kompeten yang mampu memimpin dunia; dan (11) untuk menyemai rasa cinta kepada tanah air dan memupuk perpaduan antara pelbagai kaum.

Jika diteliti kesemua 11 tujuan Pendidikan Islam, ianya menjurus kepada matlamat Pendidikan Islam itu sendiri iaitu untuk mencapai kesempurnaan kendiri (roh) dan memenuhi keperluan dunia untuk bekalan akhirat (al-Nahlawi, 1979; al-'Abrashi, 1969; Said Nursi, 2013; dan al-Attas, 2018) . Perkara ini dapat dibuktikan melalui manifestasi Falsafah Pendidikan Islam, iaitu:

Pendidikan Islam merupakan suatu usaha berterusan untuk menyampaikan ilmu, kemahiran dan penghayatan Islam berdasarkan al-Quran dan al-Sunnah bagi membentuk sikap, kemahiran, keperibadian dan pandangan hidup sebagai hamba Allah SWT yang mempunyai tanggungjawab untuk membangun diri, masyarakat, alam sekitar dan negara ke arah mencapai kebaikan di dunia dan kesejahteraan abadi di akhirat (Bahagian Kurikulum Pendidikan Islam Dan Moral, 2002)

\subsection{INSAN DAN KEPERLUAN PENDIDIKAN MENGIKUT TAHAP}

Proses pendidikan insan adalah bergantung kepada tahap perkembangan diri insan. Bersesuaian dengan saranan Saidina Ali RA tentang pendidikan berdasarkan kepada tahap umur dan kematangan anak-anak. Di mana Saidina Ali RA membahagikan umur insan kepada tiga tahap iaitu tujuh tahun pertama iaitu dari umur 0-7 tahun, kemudian tujuh tahap yang kedua iaitu 8-14 tahun dan kemudiannya tujuh tahun ketiga iaitu 15-21 tahun (Nahjul Balaghah,1989). Menurut Saidina Ali, pada fasa tujuh tahun yang pertama, menjadikan anak seperti raja iaitu dengan sedaya mungkin memenuhi keperluannya dengan penuh ikhlas dan kasing sayang. Manakala fasa berikutnya adalah fasa menjadikan anak seperti tawanan perang dengan memberikan mereka hak dan tanggungjawab dengan beebrapa sekatan bagi membentuk disiplin. Pada fasa ini ketegasan dan hukuman yang bersesuaian boleh digunakan bagi tujuan mendidik. Pada fasa 7 tahun berikutnya, jadikan anak sebagai sahabat. Pembahagian tahap umur ini juga bersesuaian dengan hadis Nabi SAW berkaitan dengan kewajipan memberikan pengajaran mengenai solat kepada anak-anak yang bermaksud:

"Perintahkanlah anak-anak kamu untuk melaksanakan solat apabila sudah mencapai umur tujuh tahun. Apabila sudah mencapai umur sepuluh tahun maka pukullah dia apabila tidak melaksanakannya serta pisahkanlah tempat tidur 
mereka." (Berkata an-Nawawi, hadith hassan sebagaimana diriwayatkan oleh Abu Dawud dengan sanad yang hassan. No. Hadith: 495).”

Menurut ahli Psikologi, perkembangan manusia berbeza mengikut tahap dan peringkat kehidupannya (Piaget, 1969; Erikson, 1950; Vygotsky, 1979). Jean Piaget (1969) membahagikan perkembangan kognitif manusia kepada empat fasa iaitu bermula dengan umur 0-2 tahun yang dipanggil sebagai peringkat sensori motor, kemudian 2-7 tahun iaitu peringkat Pra-operasi, 7-11 tahun iaitu peringkat operasi konkrit dan 11-ke atas yang dipanggil peringkat operasi formal. Secara umumnya, Piaget mengasaskan teori perkembangan beliau melalui empat konsep asas iaitu: skema, asimilasi, akomodasi dan keseimbangan.

Piaget (1969) berpendapat setiap manusia dilahirkan dengan skema yang berbentuk umum dan berkembang dengan pertambahan umurnya. Skema yang dimaksudkan di sini adalah struktur kognitif yang membolehkan manusia mengurus dan menyesuaikan diri dengan keadaan persekitaran. Manakala asimilasi pula ialah sebuah proses kognitif yang membolehkan seseorang menyerap maklumat baru atau pengalaman baru ke dalam skema yang sedia ada. Proses asimilasi ini berlaku sepanjang masa kerana manusia sentiasa berinteraksi dengan maklumat dan pengalaman baru dalam kehidupannya. Manakala, akomodasi pula ialah proses penyesuaian yang menghasilkan perubahan serta perkembangan skema. Di mana maklumat atau pengalaman baru yang diterima dan sesuai dengan skema sedia ada maka maklmat atau pengalaman tersebut akan diterima. Manakala, jika maklumat atau pengalaman baru yang diterima tidak sesuai dengan skema sedia ada maka samada maklumat itu akan diubahsuai atau ditolak. Proses ini akan berlaku secara berterusan sehingga seseorang itu memperoleh sebuah kefahaman yang stabil bagi melakukan kemahiran. Akhirnya tahap keseimbangan akan dapat dicapai apabila seseorang dapat menyeimbangkan proses asimilasi dan akomodasi yang berlaku ke dalam skema sedia ada. Jika proses asimilasi tidak dapat dilakukan, maka pengubahsuaian skemaatau skema baru akan dibentuk.

Empat peringkat perkembangan kognitif manusia dijelaskan seperti berikut. Pada peringkat sensori motor (0-2 tahun), bayi belajar interaksi deria dengan persekitaran. Mereka dapat memerhatikan benda melalui penglihatan mahupun pendengaran. Setelah berumur 2 tahun, bayi memperoleh kepercayaan tentang pengekalan objek, iaitu dia sedar objek itu akan terus wujud walaupun tidak dapat disentuh atau dilihat. Pembelajaran bayi pada waktu ini adalah berdasarkan kepada pengalaman sensori dan motor.

Apabila memasuki peringkat berikunya iaitu Pra-operasi (2-7 tahun), kanak-kanak sudah mula berfikir secara logik tetapi belum boleh menguasai peraturan pemikiran logik dan masih belum boleh mengoperasikan konsep. Mereka boleh berimaginasi dan masih belum boleh membezakan antara benda yang hidup dan yang mati. Dalam fasa ini kanak-kanak berfikir secara egosentrik iaitu melihat semua perkara daripada perspektif mereka sahaja. Perkembangan paling besar pada ketika ini adalah perkembangan Bahasa. Pada peringkat berikutnya, iaitu peringkat operasi konkrit (7-11 tahun), perkembangan pemikiran kanak-kanak menjadi lebih fleksibel. Pada waktu ini mereka sudah mula boleh berfikir berdasarkan peraturan logik dan tersusun namun masih terbatas kepada perkara yang bersifat konkrit. Boleh memberi fokus kepada beberapa perkara dalam satu masa dan boleh menerima pandangan daripada orang lain.

Akhirnya, pada peringkat operasi formal (11-ke atas). Di mana kanak-kanak telah berada pada usia awal remaja. Mereka sudah boleh memahami perkara yang bersifat abstrak, memahami teori hubungan antara sebab dan akibat kemudian mengambilkira perkara yang bersifat kemungkinan dan reality. Mereka juga mempunyai kebolehan menyelesaikan masalah berdasarkan kepada pengetahuan, pengalaman dan kemahiran.

Selain daripada Piaget (1969), teori perkembangan kognitif ini turut dibincangkan oleh ahli Psikologi Vygotsky (1979). Beliau berpendapat, manusia membina kefahaman sendiri berdasarkan kepada pengalaman yang diperolehi daripada persekitarannya. Di sini, manusia akan menyesuaikan pengetahuan yang baru diterima dengan pengetahuan sedia ada untuk membentuk pengetahuan yang baru. Ia boleh terjadi juga melalui interaksi sosial dengan persekitaran iaitu melalui bantuan dan sokongan yang diberikan daripada persekitaran yang membantu mendapatkan pengetahuan tersebut. Dua konsep penting yang diketengahkan melalui teori ini adalah, actual developmental level iaitu kebolehan seorang mendapatkan sesuatu pengetahuan sendiri tanpa bantuan orang lain dan zone of proximal development iaitu kemampuan seseorang mendapatkan sesuatu pengetahuan dengan bantuan orang lain. Bersama dengan konsep yang kedua ini diperkenalkan scaffolding iaitu merujuk kepada system sokongan yang berada dalam persekitaran seseorang yang membantunya mendapatkan seseuatu pengetahuan. Konsep ini dilakukan menerusi bimbingan menerusi soalan-soalan dan interaksi yang bersifat positif (Haliza Hamzah \& Joy N. Samuel, 2010).

Menurut Erikson (1950) perkembangan manusia adalah sangat berkaitan dengan hubungan ibu-bapa dengan anak selain daripada merasa dihargai dan disayangi. Erikson memperkenalkan lapan peringkat kehidupan manusia. Peringkat pertama iaitu pada usia (0-1 tahun) dinamakan sebagai trust-mistrust, di mana dalam usia ini bayi sedang membina kepercaya terhadap diri dan persekitarannya, jika semua keperluannya diperoleh maka kepercayaan akan terbentuk namun jika tidak maka ketidakpercayaan dan ketakutan akan terbentuk. Seterusnya, pada tahap 1-3 tahun adalah peringkat autonomy- shame and doubt, di mana pada usia ini tumpuan adalah kepada penguasaan autonomi melalui penguasaan kemahiran, jika penguasaan kemahiran kerap kali gagal maka perasaan tidak percaya diri akan mula berakar. Dan apabila keadaan kegagalan itu tidak disambut baik oleh ibu bapa dan persekitaran perasaan malu dan rendah diri akan terbentuk dalam diri.

Manakala, pada peringkat berikutnya iaitu pada usia 3-6 tahun iailah peringkat initiative-guilt. Pada usia ini kanak-kanak sedang giat melakukan eksplorasi perkara-perkara baru dalam kehidupan dan menemui cabaran-cabaran baru yang menerujakan. Jika pada waktu ini mereka mendapat sokongan daripada ibu bapa maka mereka akan menghadapi situasi ini dengan penuh kegembiraan dan keterujaan. Namun jika sebaliknya, mereka dimarahi maka akan mewujudkan rasa bersalah dalam diri, kebencian dan tidak mampu. Berikutnya, pada usia 6-12 tahun, fasa ini di panggil industry -inferiority. Dalam fasa ini, kanak-kanak belajar untuk memiliki kemahiran seperti orang dewasa seperti penjagaan diri, bekerja dengan produktif dan berkawan. Jika keinginan mereka ini tidak disokong oleh ibu bapa maka mereka akan membentuk rasa serba kekurangan dan hilang percaya diri.

Seterusnya, pada peringkat umur 12-19 tahun ialah tahap identity-role confusion, di mana pada usia awal remaja ini, mereka sedang mencari identiti diri dengan mengintegrasikan pelbagai peranan yang wujud dalam dirinya kepada satu corak yang seimbang. Jika titik keseimbangan ini tidak berjaya ditemui maka dia akan membentuk kecelaruan identiti dan putus asa. Kemudian pada usia berikutnya iaitu antara 19-40 tahun ada fasa intimacy-isolation. Manusia apa waktu ini kebiasaannya sedang mencari pasangan hidup. Persoalan yang paling besar untuk fasa ini adalah untuk menyayangi seseorang, dia perlu merasa selamat dari segi identiti, autonomi dan kepercayaan. Fasa berikutnya, adalah fasa dewasa iaitu antara umur 40-65 tahun. Fasa ini dipanggil generativity-stagnation. Mereka yang berjaya menghadapi kesemua enam peringkat sebelum ini dia akan dapat merasai kegembiraan dan makna dalam kehidupan. Fasa akhir adalah fasa 
Integrity-despair iaitu pada usia 65 tahun ke atas.Fasa ini adalah fasa terakhir kehidupan manusia. Di mana jika berjaya menyelesaikan konflik pada fasa sebelumnya dia akan merasa tenang dan berpuas hati. Jika tidak, dia akan kecewa kerana peluang dan peranan yang semakin hilang.

Selain daripada keperluan dan perkembangan manusia yang berperingkat. Hakikat insan itu sendiri memiliki dua unsur yang harus diakui kesatuannya. Dua unsur tersebut adalah fizikal dan ruh (Al-Attas, 1990). Fizikal adalah perkara yang memberi bentuk kepada seorang insan, manakala aspek ruhnya adalah aspek yang membezakannya dengan makhluk lain yang dijadikan Allah SWT. Ruh ini terbahagi kepada tiga iaitu jiwa nabatiyyah (tumbuhan), jiwa hayawaniyyah, jiwa insyaniyyah (Al-Attas, 1990). Jiwa nabatiyyah mempunyai kekuatan nutrisi, tumbesaran dan reproduksi. Secara umumnya, kekuatan atau daya ini dimiliki juga oleh tumbuhan dan haiwan. Manakala, jiwa hayawaniyyah mempunyai kebolehan bergerak (muharrikah-motive) dan membuat anggapan (mudrikahperceptive). Kedua-dua kekuatan ini memiliki dua bahagian. Bahagian pertama bagi kebolehan bergerak adalah penggerak tindakan (arouser of action) iaitu berperanan untuk mengarahkan tindakan berdasarkan apa yang difikirkan berfaedah atau berbahaya; dan pelaku tindakan (actuator) menggerakkan saraf, otot, tendon, ligamen berdasarkan apa yang diisyaratkan oleh penggerak tindakan. Jika penggerak tindakan beranggapan sesuatu itu bermanfaat baginya, maka ia akan menggerakkan pelaku tindakan ke arahnya. Manakala, jika ia beranggapan sesuatu perkara itu berbahaya, maka ia akan menggerakkan pelaku tindakan untuk menjauhinya. Anggapan yang dibuat ini dipengaruhi oleh daya keinginan (al-shahwaniyyah) dan daya kemarahan (al-ghadabiyyah). Manakala, kebolehan membuat anggapan (mudrikah-perceptive) terbahagi kepada dua iaitu deria luaran iaitu sentuhan, bau, rasa, penglihatan dan pendengaran dan deria dalaman iaitu common senses, representation, estimation,retention-recollection dan imaginasi iaitu (i)penerima yang sensitif kepada bentuk yang boleh dilihat dan (ii) penerima rasional kepada perkara yang boleh difahami.

Jiwa insyaniyyah mempunyai dua kekuatan intelek iaitu aktif ('amilah) dan kognitif ('alimah). Aktif intelek adalah yang menggerakkan tingkah laku manusia sejajar dengan teori yang terdapat dalam kognitif. Apabila ia berinteraksi dengan daya bergerak (mudrikah-motive) yang ada dalam jiwa hayawaniyyah, ia akan menerbitkan emosi. Manakala apabila is berinteraksi dengan daya anggapan, representative, estimative dan imaginative ia menggerakkan objek fizikal dan menerbitkan kemahiran insan. Kemudian, apabila berinteraksi dengan imaginasi rasional ia akan menerbitkan premis dan konklusi. Daya ini juga menerbitkan tingkah laku beradab dalam diri insan dan pengenalan kepada sifat yang baik dan tidak baik (Al-Attas, 1990).

\subsection{WATAK PENDIDIK MENERUSI KONSEP $5 \mathrm{M}$}

Model pengajaran 5 mim adalah berdasarkan kepada 5 ciri penting yang perlu diperolehi oleh seorang guru terutama GPI. Lima ciri tersebut ialah mudarris, mu 'alim, murabbi, mursyid dan mu'addib (Ab. Halim Tamuri et al. 2006). Mudarris ialah seorang guru atau GPI khususnya yang berjaya menampilkan diri sebagai seorang tenaga pengajar yang cemerlang berdasarkan kepada lima ciri penting iaitu keperibadian, kaedah pengajaran yang berkesan, berjaya mewujudkan suasana pengajaran bilik darjah yang kondusif dan cekap dalam melakukan keputusan profesional. Mu'alim pula merujuk kepada tugasan guru sebagai penyampai maklumat, disiplin dan ilmu pengetahuan kepada pelajar. Seterusnya, guru sebagai murabbi iaitu meliputi tugas guru sebagai pendidik dan penjaga pelajar dalam usaha mengekalkan keadaan fitrah pelajar dengan penuh kasih sayang. Selain itu, guru turut berperanan sebagai mu'addib iaitu peranan guru selaku pembimbing akhlak pelajar berdasarkan nilai ta'dib yang disarankan dalam Quran dan Sunnah dan akhirnya Mursyid. Guru sebagai Mursyid menjelaskan peranan guru dari sudut kepimpinan guru di dalam kelas yang merujuk kepada ciri kepimpinan Rasulullah s.a.w. Lakaran model pengajaran 5 mim adalah seperti dalam Rajah 1, seperti berikut:

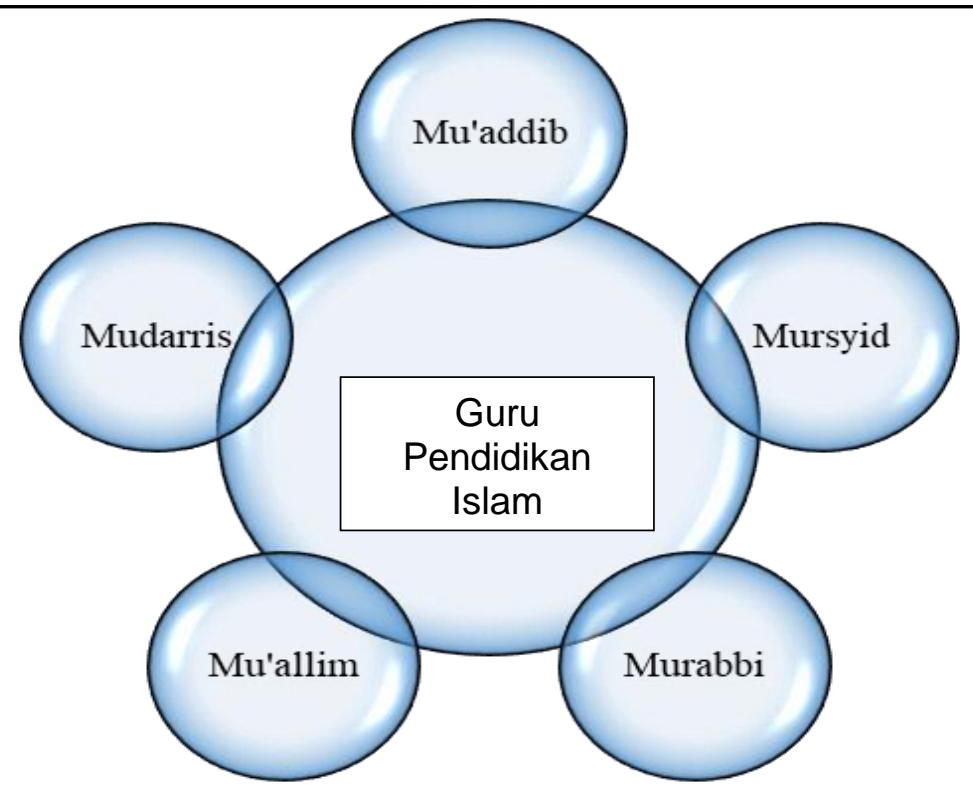

Rajah 1 Model pengajaran 5 Mim (Ab. Halim Tamuri et al. 2006)

Terdahulu daripada model ini, al-Attas (1999) telah membincangkan berkaitan dengan peranan guru sebagai Muaddib yang merujuk kepada hakikat tujuan Pendidikan Islam adalah untuk menghasilkan seorang insan yang beradab. Jadi proses yang paling tepat 
bagi mencapai matlamat tersebut adalah proses ta'dib. Proses ini merangkumi dua proses lainnya iaitu tarbiyyah yang bermaksud penyuburan yang baik dan ta'lim iaitu ilmu dan pengajaran. Adab lahir menerusi ilmu yang benar kemudian mendatangkan makna kepada individu sehingga dia boleh melihat letak duduknya sesuatu perkara secara hikmah dan adil. Al-Attas (1999) sekali gus telah meletakkan visi besar yang harus digalas oleh Guru Pendidikan Islam adalah sebagai Muaddib.

Kedua-dua model ini hakikatnya menyokong satu sama lain. Ab. Halim et.al (2006) melihat 5 komponen guru ini harus dimiliki secara kolektif oleh Guru Pendidikan Islam bagi memberikan fungsi yang optimum. Berdasarkan kepada asas yang diletakkan oleh AlAttas (1999) dapatlah difahami bahawa, peranan sebagai muaddib adalah visi besar yang harus diletakkan dalam minda setiap guru terutama Guru Pendidikan Islam kerana di sana terlihatnya proses ta'dib bagi menyokong tujuan pendidikan Islam itu sendiri. Manakala peranan lainnya adalah penting untuk digunakan untuk menyokong tugas muaddib guru pendidikan Islam terutama ketika menjalankan aktiviti pengajaran dan pembelajaran. Apatah lagi bagi meraikan kepelbagaian tahap dan peringkat keperluan insan yang dididik. Lakaran gabungan kedua-dua model ini adalah seperti Rajah 2 berikut:

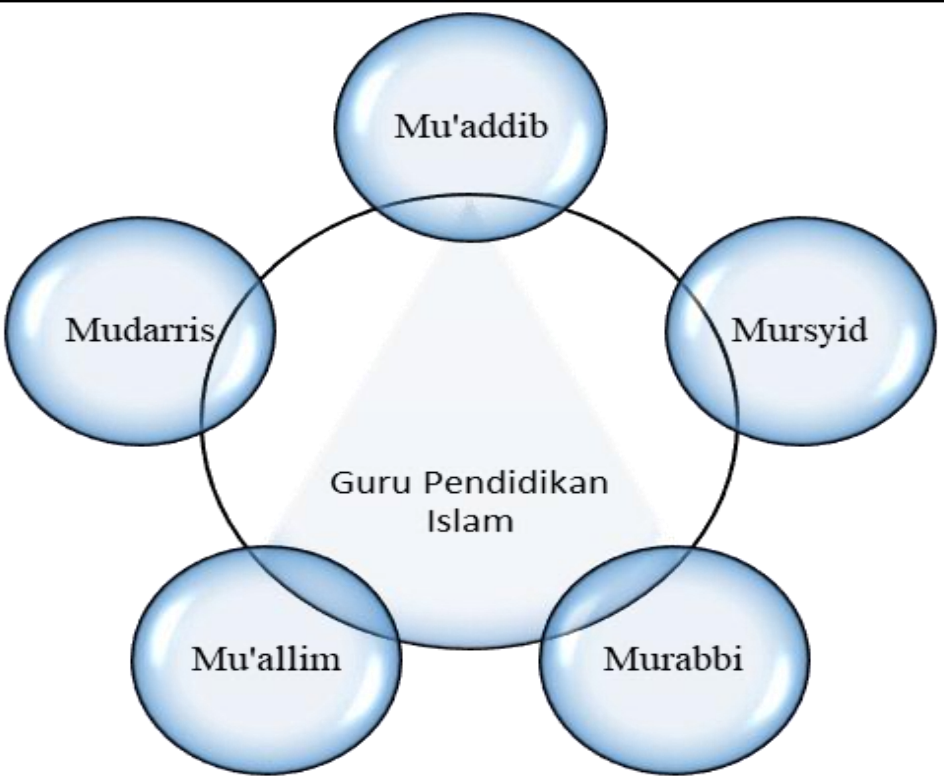

Rajah 2 Gabungan Model Ta’dib (Al-Attas, 1999 ) \& Model 5 Mim (Ab. Halim Tamuri et al,2006)

Amalan pengajaran GPI berdasarkan kepada model pengajaran 5 Mim yang memiliki 5 dimensi utama iaitu domain mudarris, mu 'allim, mursyid, mu'addib dan murabbi (Ab. Halim Tamuri et al. 2006) adalah seperti berikut.

\section{a) Mudarris}

Mudarris merupakan kata nama pelaku ( $\left.f a^{\prime} i l\right)$ kepada Tadris yang merupakan kata terbitan kepada perkataan darrasa dan darasa. Keduadua kata dasar ini membawa maksud yang berbeza. Darasa merupakan perkataan Bahasa Arab yang bermaksud belajar. Manakala Darrasa juga merupakan perkataan Bahasa Arab dan bermaksud ajar (Ruhi Ba'albaki 2004). Darasa telah disebut di dalam beberapa ayat dalam Quran dan Hadis dalam pelbagai bentuk. Dalam surah al-An'am ayat 105 perkataan darasa hadir dalam bentuk fi'1 madi yang bermaksud perbuatan yang telah berlaku (Al-Quran, 6:105). Begitu juga dalam Surah al-A'raf ayat 169. Melalui ayat ini perkataan darasa ini ialah perbuatan belajar yang dilakukan secara berulang-ulang dan mengambil iktibar serta memahami pelajaran itu secara mendalam (Al-Sobuni 2004). Manakala ayat dalam surah Ali Imran:79 dan surah Al-An'am ayat 156 secara langsung menerangkan peranan guru yang bukan sahaja mengimani dan memahami apa yang disampaikan malah turut mengamalkan dalam kehidupan.

Melalui tiga-tiga ayat ini dapat disimpulkan maksud darasa adalah belajar dan Tadris ialah proses yang dilakukan sewaktu belajar yang melibatkan pengulangan, kefahaman dengan menggunakan kesemua indera manusia (Ali Imran 3:79; Al-An'am 6:156; Al'Araf 7: 169; Saba' 34: 44; Al-Qalam 68:37; Ibnu Majah 1997,no hadis 1344, Ibnu Hanbal 2004, no. hadis 411; Muslim 1994, no.hadis 215). Walaupun perkataan darrasa tidak dibahas secara langsung di dalam a-Quran namun peranannya dalam perbuatan belajar dan proses Tadris adalah penting.

Mudarris selaku pelaku kepada kata terbitan Tadris secara kesimpulannya merujuk kepada peranan yang dimainkan oleh guru untuk menyampaikan, menjelaskan, memberi kefahaman secara berulang-ulang sehingga pelajar memahami pelajaran yang disampaikan (Ruhi Ba'albaki 2004). Menurut Ibnu Khaldun dalam an-Na'miy (1994) menegaskan bahawa guru harus memastikan kesemua pelajarnya faham sesuatu topik itu dengan baik sebelum berpindah kepada topik yang baru.

Oleh itu, domain mudarris dalam kajian ini menumpukan kepada peranan GPI sebagai tenaga pengajar yang cemerlang dari segi pengendalian kelas dari mula sesi pengajaran sehingga ke akhirnya. GPI yang cemerlang dapat menarik perhatian pelajar terhadap subjek di awal sesi (Kamarudin 1990) iaitu dengan mengambil kira aktiviti permulaan yang menarik dengan penggunaan suara yang jelas, bahasa tubuh dan keceriaan yang ditonjolkan. Selain itu, menyuntik motivasi pelajar untuk mengikuti pembelajaran dan menstrukturkan topik pada hari itu iaitu dengan memberi maklumat tentang apa yang akan dipelajari secara ringkas. Seterusnya mengekalkan fokus di pertengahan kelas dengan menggabungkan beberapa kaedah dan teknik yang menarik dan mudah untuk diikuti selain mempraktikkan elemen penyoalan (al-Syaibani 1991; Kamarudin 1990; Kubiszyn dan Borich 1996). Akhirnya, menguasai pembelajaran di akhir sesi 
pengajaran dengan melaksanakan penutup pengajaran yang bermakna kepada pelajar dengan mengaitkan kesimpulan kepada objektif pengajaran selain aspek pengukuhan (Kamarudin 1990).

b) Mursyid

Mursyid berasal daripada perkataan arsyada yang bermaksud tunjuk. Justeru, Mursyid di sini membawa maksud pelaku kepada tunjuk iaitu penunjuk. Arsyada sama erti dengan perkataan ahda seperti yang dinyatakan oleh Allah dalam surah al-Fatihah ayat 6.

Guru sebagai mursyid memerlukan sifat yang ikhlas (Abdullah Nasih 'Ulwan 1989) seperti yang dianjurkan oleh Allah dalam surat Hud ayat 29.

Oleh yang demikian, selaku GPI, guru perlu mempamerkan sifat-sifat kepimpinan yang boleh dicontohi oleh pelajar di dalam kelas. Selaku Mursyid GPI perlu memiliki ciri-ciri kepimpinan yang tinggi dengan mencontohi ciri kepimpinan Rasulullah s.a.w. Justeru, aspek kepimpinan yang difokuskan dalam kajian ini merangkumi aspek kepimpinan di dalam bilik darjah.

c) Mu'allim

Mu'allim ialah pelaku kepada kata terbitan Ta'lim iaitu pengajaran atau pelajaran yang berasal daripada kata dasar 'Allama yang bermaksud ajar (Ruhi Ba'albaki 2004). Contoh ayat Quran yang menyebut perkataan 'Allama ialah surah al-Baqarah ayat 31-32.

Menurut Ibnu Kathir (2001) Allah telah memberitahu Adam a.s nama kesemua benda yang perlu diketahui oleh manusia di dunia untuk memberi kemuliaan kepadanya. Ayat ini secara tidak langsung menjelaskan bahawa Allah adalah sebenar-benar Mu'allim dan Dia merupakan sumber ilmu yang mutlak. Selain itu, Nabi s.a.w. turut digelar sebagai mu'allim dan Murabbi merujuk kepada tugas baginda memberitahu perkara yang tidak diketahui oleh orang lain(Abdullah Nasih 'Ulwan 2002; Ab Halim Tamuri dan Mohamad Khairul Azman Ajuhary 2010). Justeru mu'allim yang sebenar hanya akan berpandukan kepada Allah dan RasulNya sebagai sumber keilmuan mereka yang utama (Al-Ghazali t.t; Al-Attas 1990).

Ayat di atas turut disokong oleh ayat-ayat lain di dalam al-Quran (Ar-Rahman 55:1-4; Al-'Alaq 96:4-5; Al-Ma'idah 5:100; AlBaqarah 2:32, Al-Baqarah 2:101, An-Nisa' 4:113, Al-Baqarah 2:239, Toha 20:71, Syu'ara' 26:49) dan hadis (Bukhari no.hadis 170; Muslim no.hadis 20; Ahmad no.hadis 379; Tirmizi no.hadis 46). Menurut Syed Hussein Nasr (1987) ta lim bermaksud satu proses pemindahan pengetahuan daripada seorang guru kepada anak didiknya. Justeru, mu'allim dapat difahami sebagai tugas guru sebagai penyampai ilmu pengetahuan kepada pelajar berlandaskan daripada sumber yang mutlak sebagai sumber utama tanpa menafikan hak akal dalam mencapai ilmu pengetahuan. Oleh yang demikian, domain mu'allim dalam kajian ini merujuk kepada peranan tersebut yang turut terangkum dalam peranan guru sebagai Muaddib.

\section{d) Murabbi}

Murabbi berasal daripada perkataan rabba yang bermaksud mendidik, mengasuh, membesarkan (Ruhi Ba'albaki 2004).Murabbi juga merupakan pelaku kepada kata terbitan tarbiyah yang ditakrifkan sebagai perbuatan mendidik, mengasuh, membesarkan dan memberi kasih sayang (Tengku Ghani Tengku Jusuh 2002). Al-Attas (Wan Mohd Nor, 2017) turut mentakrifkannya sebagai pengasuhan yang baik. Perkataan tarbiyah boleh dirujuk dalam firman Allah dalam surah al-Isra' ayat 24.

Antara ciri-ciri guru Rabbani yang diketengahkan oleh al-Ghazali (t.t) dan Ahmad Mohd Salleh (1997) ialah berperanan seperti ibu bapa atau penjaga kepada murid di sekolah dengan membina hubungan yang ikhlas dengan penuh kasih sayang sehingga timbul kepercayaan antara keduanya. Selain itu guru perlu berusaha menitipkan sifat Rabbani dalam pemikiran dan tindakan pelajar (Surah Ali Imran 3:79) agar pembentukan insan yang cemerlang dunia dan akhirat dapat di lahirkan melalui tarbiyah yang dilakukan oleh guru murabbi. Justeru, domain murabbi dalam kajian ini akan memfokuskan kepada peranan GPI mendidik, menjaga dan mengasuh pelajar dari sudut keperluan emosi dan fizikalnya dengan penuh kasih sayang. Peranan ini turut terangkum dalam peranan guru sebagai Muaddib.

e) $\quad$ Mu'addib

Mu'addib merupakan pelaku kepada kata terbitan $T a$ 'dib yang bermaksud pendidikan (Ruhi Ba'albaki 2004). Pendidikan ini menjurus kepada aspek akhlak seperti yang dijelaskan oleh al-Ghazali (1997) bahawa proses Ta'dib melibatkan pendidikan daripada dua aspek penting iaitu aspek fizikal dan rohani yang merangkumi percakapan dan niat bagi menghasilkan akhlak yang baik. Proses ini hanya akan berjalan dengan baik dengan penguasaan ilmu yang tinggi dan disiplin yang ketat. Pandangan al-Ghazali ini disokong oleh al-Attas (1986) yang menyatakan bahawa istilah Ta'dib lebih tepat untuk mengistilahkan GPI. Hal ini kerana, GPI mempunyai peranan yang besar dalam pembentukan jati diri insan yang berakhlak mulia dan cemerlang bukan sahaja di dunia malah di akhirat. Al-Attas turut merumuskan, bagi memastikan proses ta'dib ini berjaya mencapai matlamatnya, GPI harus merangkumkan di dalamnya, peranan mereka sebagai Muallim dan Murabbi.

Oleh yang demikian, untuk domain $m u$ 'addib kajian ini akan memfokuskan kepada sebagai pendidik akhlak pelajar iaitu mempamerkan sifat yang terpuji, menjadi contoh teladan kepada pelajar, bersifat zuhud (Abdullah Nasih 'Ulwan, 1968) dan menjaga maruah diri dari sudut percakapan, perbuatan dan cara berpakaian (Muhammad Uthman El-Muhammadi, 1991 dalam Ahmad Mohd Salleh,1997). Ia adalah refleksi daripada kefahaman ilmu dan asuhan yang baik (Wan Mohd Nor, 2017).

Kesimpulannya, GPI yang cemerlang ialah GPI yang berjaya mengamalkan kelima-lima konsep guru dalam Islam seperti yang telah dibincangkan dengan meletakkan peranan guru sebagai Muaddib sebagai visi utama bagi menggerakkan proses ta'dib. Manakala peranan yang lainnya adalah penyokong kepada peranan utama tersebut berdasarkan kepada kesesuaian tahap dan peringkat pengajian yang dihadapi oleh setiap GPI begitu juga dengan konteks pengajaran dan pembelajaran dalam kelas. 


\subsection{KEPERLUAN WATAK SELARAS TAHAP PENGAJIAN}

Perkembangan manusia disokong oleh ilmu yang diperoleh bagi memberikan makna kepada keseluruhan kehidupannya sebagai hamba Allah dan khalifatullah. Selaras dengan tujuan pendidikan untuk melahirkan peribadi insan yang beradab, guru yang menjadi penggerak kepada tujuan tersebut harus memainkan peranan yang tepat bagi memaknai usaha mendidik. Di sinilah pentingnya untuk meletakkan garis panduan kepada peranan yang wajar dilaksanakan oleh para guru merentas setiap peringkat pengajian.

Al-Attas (1980) berpandangan, pendidikan yang paling mustahak adalah di peringkat pengajian tinggi (Wan Mohd Nor, 2017). Di mana, tempat para pendidik sedang disediakan. Para pendidik inilah yang perlu dipersiapkan terlebih dahulu sebelum berdepan dengan para anak didiknya kerana dialah yang bertanggungjawab mencorakkan generasi mendatang. Dalam konteks individu di peringkat pengajian tinggi, sekali pun dia bukan bergelar tenaga pengajar di mana-mana institusi pengajian, secara umumnya mereka adalah pendidik kepada konteks di mana mereka berada. Contohnya, dalam keluarga dan masyarakat. Pada peringkat tinggi, umumnya para pelajarnya adalah dalam kalangan umur 18 tahun ke atas. Di mana pada usia ini, mereka digelar akhir remaja, awal dewasa dan dewasa (Erikson, 1950). Dari segi perkembangan kognitif juga sudah berada di tahap yang matang, memahami perkara yang bersifat abstrak, memahami teori hubungan antara sebab dan akibat kemudian mengambilkira perkara yang bersifat kemungkinan dan realiti. Mereka juga mempunyai kebolehan menyelesaikan masalah berdasarkan kepada pengetahuan, pengalaman dan kemahiran (Piaget, 1969). Perkembangan minda yang stabil dan matang sudah bersedia untuk menerima dan memahami perkara-perkara dasar dan bersifat menyeluruh.

Dalam proses meletakkan insan dalam ruh insaniyyahnya, peringkat usia ini adalah keadaan insan yang paling sesuai memandangkan perkembangan mindanya stabil dan semakin matang. Justeru, peranan guru harus ditumpukan kepada aspek ta'dib iaitu terangkum di dalamnya ta'lim iaitu memberikan ilmu dan pengajaran berdasarkan kepada ilmu yang benar dan menatijahkan tindakan dan tingkah laku yang benar iaitu tingkah laku beradab (Wan Mohd Nor, 2017). Adab di sini bukan sahaja menyentuh aspek akhlak namun mengetahui letak duduk sesuatu perkara pada suatu keadaan dan masa yang benar natijah daripada hikmah dan adil. Ia harus bermula dengan persediaan minda yang baik iaitu melalui ilmu yang benar iaitu ilmu yang bersumberkan Quran dan Sunnah sebagai yang utama. Adab terkait dengan hubungan insan dengan Pencipta, hubungan insan sesama insan dan hubungan insan dengan makhluk lain. Pelaziman (training) adalah sesuatu yang bersifat sementara dan kurang sesuai untuk tahap umur ini (Wan Mohd Nor, 2017). Walau bagaimanapun, proses tarbiyyah iaitu penyuburan yang baik adalah sokongan untuk membantu proses ta'lim melalui contoh tauladan yang ditunjukkan. Bersesuaian dengan anjuran daripada Saidina Ali RA iaitu untuk bersahabat dengan anak-anak yang berada dalam usia antara 15 ke 21 kerana pada tempoh ini banyak perkara yang harus dibincangkan kerana banyak pengalaman baru yang ditempuhi(Nahjul Balaghah). Tambahan pula, menurut Erickson (1950), pada peringkat ini manusia sedang mencari kestabilan identiti, emosi dan autonomi dan kepercayaan. Maka ilmu yang benar dan kerangka pemikiran yang bersumberkan sumber yang benar akan membantu mereka menghadapi fasa ini dengan baik (Erickson, 1950).

Manakala pada usia anak-anak di sekolah menengah, iaitu usia mereka di antara 13-18 tahun, mereka dikategorikan berada dalam fasa awal remaja dan remaja. Menurut Erickson (1950) anak-anak pada usia ini sedang dalam fasa mencari identiti. Untuk menyokong fasa ini, ilmu yang benar juga harus diberikan dengan pengukuhan pelaziman dan penjelmaan contoh yang boleh diikuti harus diberikan oleh GPI. Proses ini memerlukan GPI berperanan besar sebagai Mua'llim, Murabbi, Mursyid dan Mudarris (Al-Attas, 1986; Ab. Halim Tamuri et al, 2006). Dalam menyampaikan ilmu yang benar, GPI harus memiliki kemahiran sebagai tenaga pengajar yang baik dari segi kemahiran pengajaran dan penampilan. Proses penerapan disiplin juga harus diseimbangkan dengan kefahaman yang benar agar pelaziman yang dilakukan berkekalan membentuk identiti dalam diri seseorang.

Selain itu, bagi anak-anak yang berada di peringkat sekolah rendah pula adalah anak-anak yang berada dalam fasa kanak-kanak dan awal remaja iaitu pada usia 7-12 tahun. Anak-anak pada usia ini sebahagiannya masih memerlukan perhatian dari segi pengasuhan dan kasih sayang terutamanya bagi mereka yang berusia 7 tahun. Jadi GPI harus memegang watak Murabbi disokong dengan Mudarris bagi memastikan proses tarbiyyah berjalan dengan baik. Apabila usia mereka memasuki 8-12 tahun, ini adalah fasa disiplin maka proses tarbiyyah harus diteruskan disokong dengan kefahaman kerana perkembangan mindanya semakin meningkat daripada operasi konkrit ke arah operasi formal iaitu sudah mula boleh berfikir berdasarkan peraturan logik dan tersusun namun masih terbatas kepada perkara yang bersifat konkrit ke arah boleh memahami perkara yang bersifat abstrak, memahami teori hubungan antara sebab dan akibat kemudian mengambil kira perkara yang bersifat kemungkinan dan realiti (Piaget, 1969).

Akhirnya, bagi kanak-kanak yang berusia 0-7 tahun iaitu lazimnya berada di alam Pra sekolah. Kanak-kanak ini memerlukan asuhan yang baik dan seorang Murabbi yang bertindak seperti ibu bapa mereka. Fasa ini kanak-kanak sedang membina kepercayaan dengan persekitaran, menguasai kemahiran baru dan sedang meneroka perkara-perkara baru untuk membina keyakinan diri (Erickson, 1950). Di samping itu, dari segi perkembangan mindanya mereka dalam fasa pengukuhan skema pemikiran melalui asimilasi informasi dan pengalaman-pengalaman baru (Piaget, 1969). Kanak-kanak ini amat memerlukan sokongan dan bimbingan daripada guru-guru dan persekitaran untuk membantunya berkembang (Vygotsky, 1979).

Kesimpulannya, semakin tinggi tahap perkembangan umur dan minda seseorang dia memerlukan proses sokongan yang berbeza daripada persekitarannya. Begitu jugalah refleksi yang dapat dilihat dalam konteks peranan yang perlu diamalkan oleh GPI. Kelima-lima watak GPI harus diteliti dan dimiliki oleh setiap GPI. Visi besarnya adalah sebagai Muaddib yang sejajar dengan proses ta'dib yang menunjangi Pendidikan Islam secara keseluruhan. Di tambah dengan sokongan daripada watak-watak lain mengikut konteks dan kematangan pelajar yang dihadapi dalam setiap pengajarannya.

\subsection{KESIMPULAN}

Kajian ini memberikan implikasi kepada Guru Pendidikan Islam secara langsung ke arah menyediakan diri dengan ilmu tertentu untuk memainkan watak-watak penting tersebut dalam pengajaran. Selain itu, penyedia pendidikan bagi GPI juga dapat menggunakan dapatan kajian ini bagi memandu jenis program atau latihan yang bersesuaian bagi membantu meningkatkan prosefionalisme GPI dalam konteks pembentukan watak yang relevan dengan peringkat pengajian. Sebagai persekitaran yang paling hamper dengan pelajar sewaktu di institusi Pendidikan, gurulah yang harus menunjukkan contoh yang paling baik kepada pelajar. Kehadiran guru yang berkebolehan memahami 
keperluan dan keutamaan diri pelajar pada satu-satu tahap pengajian menyediakan diri pelajar ke arah pembelajaran yang lebih kondusif. Guru harus meletakkan kerangka guru Muaddib sebagai visi utama sesuai dengan proses Pendidikan yang berterusan bagi melahirkan pelajar yang beradab iaitu tahu meletakkan dirinya pada tempat yang sewajarnya dengan memahami letak duduk setiap perkara dalam kehidupannya pada tempat yang wajar. Dalam masa yang sama, komponen guru yang lain iaitu mursyid, mudarris, murabbi dan mu'allim harus disesuaikan dengan konteks pelajar. Bagi konteks pelajar yang masih kecil penekanan kepada aspek Rabb iaitu guru selaku Murabbi dan disokong dengan wataknya selaku mudarris, seterusnya bagi pelajar remaja, aspek guru sebagai mursyid harus disesuaikan dengan Muallim dan murabbi selain mudarris dan akhirnya di peringkat dewasa, guru harus berperanan selaku muaddib.

\section{Rujukan}

Ab. Halim Tamuri \& Zarin Ismail. (2004(. Hubungan Media Massa Dengan Pegangan Akhlak Dan Pengajaran Pendidikan Islam. Projek Penyelidikan. Universiti Kebangsaan Malaysia, Bangi.

Ab. Halim Tamuri, Khadijah Abd Razak, Shahrin Awaluddin, Kamarulzaman Abdul Ghani \& Mohd Aderi Che Noh. (2006). Kajian Amalan Pengajaran Pendidikan Islam Di Sekolah Rendah Dan Menengah. Seminar IRPA RMK-8, Kategori ERK 2006, 1-15.

Ab. Halim Tamuri \& Zarin Ismail. (2006). Model Guru Pendidikan Islam: konsep 5 p kertas kerja Seminar Amalan Pengajaran Guru Pendidikan Islam. Anjuran Bilik Senat, Bangunan Canselori, UKM, 1 April 2006.

Ab. Halim Tamuri \& Mohamad Khairul Azman Ajuhary (2010). Amalan pengajaran guru pendidikan Islam berkesan berteraskan konsep Mu'allim. Journal of Islamic and Arabic Education, 2(1), 43-56.

Abdullah Nasih 'Alwan. (1968). Tarbiyyah Al-Awlad Fi Al-Islam. Kaherah: Dar al-Salam Abdullah Sani Yahya. 2005a. Mengurus Disiplin Pelajar. Kuala Lumpur: PTS Professional Sdn. Bhd.

Ahmad Mohd. Salleh. (1997). Pendidikan Islam: Falsafah, pedagogi dan metodologi. Kuala Lumpur: Fajar Bakti Sdn. Bhd.

Ahmad Mohd. Salleh. (2004). Pendidikan Islam: Falsafah, Sejarah Dan Kaeah P\&P. Selangor: Fajar Bakti Sdn. Bhd.

Al-Attas Syed Muhammad Naqib. (1980). The Concept of Education in Islam. Kuala Lumpur: ABIM.

Al-Attas, Muhammad Syed Naquib. (1986). Islam, Secularism and Philosophy of the Future. London: Mansell Publishing Limited.

Al-Attas, Muhammad Syed Naquib. (1990). The Nature of Man and The Psychology of Human Soul. Kuala Lumpur: ISTAC.

Al-Attas, Muhammad Syed Naquib. (2014). Prolegomena to the metaphysics of Islam. Johor: UTM Press.

Al-Attas, Muhammad Syed Naquib. (2018). The Concept of Education in Islam. Kuala Lumpur: Ta'dib International.

Al-Attas, Muhammad Syed Naquib. (2019). Risalah untuk Kaum Musliman. Kuala Lumpur: Ta’dib International.

Al-Attas, Syed Muhammad Naquib. (2019). Islam Faham Agama dan Asas Akhlak. Kuala Lumpur: Ta'dib International.

Al-Attas, Syed Muhammad Naquib. (2019). Tinjauan Ringkas Peri Ilmu dan Pandangan Alam. Kuala Lumpur: Ta'dib International.

Al-Bukhari Muhammad Bin Ismail Abu Abdullah. (1987). Sahih Al-Bukhari. Ed. Ke-3. Beirut: Dar Ibn Kathir.

Al-Nahlawi Abdul Rahman. (1979). Usul Tarbiyyah Islamiyyah. Beirut: Dar al-Ma'asir.

Al-Shaybani, 'Umar Muhammad al-Tumi. (1991). Falsafah Pendidikan Islam. Shah Alam: Hizbi.

Al-Sobuni, Mohammad Ali. (2004). Sofwah at-Tafasir. Beirut: Dar Ehia Al-Tourath Al-Arabi.

Annasaii Jamar, Fatin Nazmin Mansor \& Mohd Aderi Che Noh (2020). Kefahaman Dan Pengamalan Nilai Islam Dalam Kalangan Pelajar "Ground Handling" Di Kolej Swasta Malaysian Aviation Training Academy (MATA) Kuantan. Jurnal Hal Ehwal Islam Selangor 4(1), 1-18.

Asmawati Suhid. (2005). Kerelevanan pendidikan nilai dan agama dalam pembentukan Masyarakat Madani. Jurnal Pendidikan Islam 11(2), 69-82.

Bahagian Kurikulum Pendidikan Islam Dan Moral. (2002). Sukatan Pelajaran Kurikulum Bersepadu Sekolah Menengah: Pendidikan Syariah Islamiyah.

Erik H. Erikson (1950). Childhood and Society. In Charles G. Morris \& Albert A. Maisto. (2005). Psychology An Introduction. New Jersey: Pearson Prentice Hall.

Ibn Khaldun Zaid 'Abdul Rahman Ibn Muhammad. 1993. Mukaddimah Ibn Khaldun. Kuala Lumpur: Dewan Bahasa dan Pustaka.

Kamaruddin Husin. (1990). Pedagogi 2. Kuala Lumpur: Logman Malaysia Sdn. Bhd.

Mohd Burhan N., Tamuri A H, \& Mohd Nordin N. (2016). Pembinaan Hubungan di antara Guru dengan Pelajar. Technical and Social Science Journal (TSSJ), 5(1), 138-148. ISSN: 2289- 7356.

Nasarudin Desa @ Man, Tengku Intan Zarina Tengku Puji \& Sabri Mohamad (2018). Menangani Keruntuhan Akhlak Masa Kini Menurut Islam. Jurnal al-Turath; 3(1),55-63.

Piaget. J. (1969). The Intellectual Development of the Adolescent.G. Caplan \& S. Labovici (Eds). Adolescence Psychosocial Perspectives. New York: Basic Books. Ruhi Ba'albaki. (2004). Al-Mawrid. Beirut: Dar al-'Ilm li Maliyin.

Sharif al-Radi, Muhammad ibn al-Husayn. (1989). Nahjul balaghah: sermons, letters and sayings of Imam Ali. Qum, Iran: Ansariyan Publications.

Vygotsky, L.S. (1979). Mind in Society: The Development of Higher Mental Process. Cambridge, MA: Havard University Press.

Wan Mohd Nor Wan Daud. (2019). Budaya Ilmu Makna dan Menifestasi dalam Sejarah dan Masa Kini. Kuala Lumpur: CASIS dan HAKIM.

Wan Suhaimi Wan Abdullah. (2019). Hakikat Insan dan Kebahagiaan. WISE 2019. Kuala Lumpur: DBP.

Wan Mohd Nor Wan Daud. (2018). Falsafah dan Amalan Pendidikan Islam Syed M. Naquib Al-Attas. Kuala Lumpur: Universiti Teknologi Malaysia. 